\title{
Using nitrogen fertiliser to decrease phosphorus loss from high phosphorus soils
}

\author{
R.J. DODD ${ }^{1,2}$, R.W. McDOWELL ${ }^{1,2}$ and L.M. CONDRON ${ }^{2}$ \\ ${ }^{1}$ AgResearch Ltd, Invermay Agricultural Centre, Private Bag 50034, Mosgiel 9053, New Zealand. \\ ${ }^{2}$ Faculty of Agriculture and Life Sciences, PO Box 84, Lincoln University, Lincoln 7647, Christchurch, New Zealand \\ richard.mcdowell@agresearch.co.nz
}

\begin{abstract}
Decline in soil phosphorus (P) concentrations is slow, and environmentally significant concentrations of $\mathrm{P}$ can be lost to water long after fertiliser application is decreased. One potential method to accelerate the decline in soil $\mathrm{P}$ concentrations is to increase plant uptake by applying nitrogen $(\mathrm{N})$. A one-year lysimeter trial investigated $\mathrm{P}$ losses to leachate on three soil types receiving three rates of $\mathrm{N}$ fertiliser $(0,150$ and 300 $\mathrm{kg} \mathrm{N} / \mathrm{ha} / \mathrm{yr}$ ) and zero or half maintenance $\mathrm{P}$ fertiliser, with regular cutting and removal of pasture. Increasing $\mathrm{N}$ input increased annual pasture yield and decreased DRP loss in leachate compared to the zero $\mathrm{N}$ treatment, without increasing nitrate or ammonium loss. Furthermore, treatments receiving half maintenance $\mathrm{P}$ at all $\mathrm{N}$ rates had lower $\mathrm{P}$ losses than the zero $\mathrm{N}$ and zero $\mathrm{P}$ treatment. Based on a cut and carry system, increasing $\mathrm{N}$ fertiliser in conjunction with decreasing $\mathrm{P}$ fertiliser has potential as a mitigation strategy to decrease $\mathrm{P}$ loss without compromising yields or increasing $\mathrm{N}$ leaching.
\end{abstract}

\section{Introduction}

Long-term application of phosphorus (P) fertilisers in excess of the crop requirements can result in a buildup of soil $\mathrm{P}$, which in turn has an increased potential for $\mathrm{P}$ loss which may impair surface water quality (Sharpley et al. 1994). This, coupled to the rapid increase in the world population and concerns over future P availability (Gilbert 2009), clearly indicate that more sustainable and $\mathrm{P}$ efficient farming practices are required. In P-rich soils, one simple method to decrease soil $\mathrm{P}$ concentrations and $\mathrm{P}$ loss would be to stop applying $\mathrm{P}$ fertilisers. However, the decline in soil $\mathrm{P}$ following a halt to $\mathrm{P}$ fertilisers has been shown to be very slow (McCollum 1991; Dodd et al. 2012). It is therefore likely that there will be long lag times, in the scale of decades or more, between the cessation of $\mathrm{P}$ fertiliser application to high $\mathrm{P}$ soils and improvements in surface water quality. An additional important consideration is the effect that withholding $\mathrm{P}$ fertiliser will have on farm production. Gillingham et al. (1990) found that withholding $P$ fertilisers for 4 years on New Zealand sheep grazed grassland led to a $10 \%$ reduction in pasture dry matter $(\mathrm{DM})$ production, despite the Olsen $\mathrm{P}$ concentration remaining within the agronomic optimum range of $20-30 \mathrm{mg} / \mathrm{kg}$ for ash and sedimentary soils in New Zealand sheep and beef pastures (Morton \& Roberts 1999). Furthermore, Dodd et al. (2012) found that the rate of decline in DM yield following cessation of $\mathrm{P}$ fertiliser to a New Zealand sheep pasture was more closely linked to the rate of decrease in water-extractable P (WEP), an indicator of the potential P loss to overland flow, than to Olsen $\mathrm{P}$. This suggests that withholding $\mathrm{P}$ fertiliser with the aim of decreasing $\mathrm{P}$ loss is likely to lead to reduction in production.

One potential strategy to decrease P loss from high $\mathrm{P}$ soils without compromising farm profitability is the cessation or decrease in $\mathrm{P}$ fertiliser applications while maintaining pasture production with $\mathrm{N}$ inputs. In mixed grass/clover pastures plant growth is generally $\mathrm{N}$-limited, and this will be especially true for soils with high $\mathrm{P}$ concentrations. Increased application of $\mathrm{N}$ fertiliser to $\mathrm{N}$-limited soils will increase pasture growth leading to increased plant uptake of $\mathrm{P}$, effectively mining $\mathrm{P}$ from the soil. Perring et al. (2009) modelled the response of soil $\mathrm{P}$ concentrations to increased additions of $\mathrm{N}$ and suggested that short term $\mathrm{N}$ fertilisation can decrease residual fertiliser $\mathrm{P}$ stored within the soil in N-limited systems. McDowell \& Monaghan (2002) also showed that increased rates of $\mathrm{N}$ fertiliser application to a New Zealand grassland soil caused a significant decrease in Olsen $\mathrm{P}$ and the total inorganic $\mathrm{P}$ fraction. Pot trials have shown that the environmentally important soil $\mathrm{P}$ forms, water extractable P (WEP) and calcium chloride extractable $\mathrm{P}\left(\mathrm{CaCl}_{2}-\mathrm{P}\right)$, can be dramatically decreased with $\mathrm{N}$ fertiliser application and regular cutting (Koopmans et al. 2004). We propose that applying a cut and carry system to critical source areas in a catchment, with high soil $\mathrm{P}$ concentrations and a high risk of $\mathrm{P}$ loss, along with the application of nitrogen over a short period of 1 year could significantly decrease P loss in the longterm. However, there has been little direct measurement of P loss to water following the implementation of this strategy. Furthermore it is important to investigate the effect of additional $\mathrm{N}$ applications on $\mathrm{N}$ losses.

This study aimed to investigate the effect of 
the following fertiliser regimes on $\mathrm{P}$ and $\mathrm{N}$ loss to subsurface leachate through a lysimeter trial. We tested the hypothesis that the addition of increased $\mathrm{N}$ fertiliser, coupled with a cessation or decrease in $\mathrm{P}$ fertiliser, will decrease subsurface P loss, by applying zero, 150 or $300 \mathrm{~kg} \mathrm{~N} / \mathrm{ha} / \mathrm{yr}$ and zero or half maintenance $P$ to three pastoral soils and measuring $\mathrm{N}$ and $\mathrm{P}$ loss to subsurface leachate and pasture production under a cut and carry regime.

\section{Methods}

\section{Lysimeter core collection}

Grazed pasture sites were selected on Allophanic, Brown and Pumice soil orders (New Zealand Soil Classification, Hewitt 2010) with similar initial topsoil
Olsen P concentrations, measured from five replicate 0-75 $\mathrm{mm}$ cores taken at each site (Table 1). The pasture was a mixture of ryegrass and clover. Twenty-four shallow lysimeter cores ( $22 \mathrm{~cm}$ deep by $16 \mathrm{~cm}$ diameter) were taken of each soil by carefully excavating around the soil core and gently lowering a PVC pipe. When the pipe was completely lowered, the soil beneath was cut with a knife to ensure a clean break. The soil cores were transported to the Invermay Agricultural Centre in Mosgiel, and an end cap, filled with acid-washed silica sand, was attached to the base of each lysimeter. Petroleum jelly was used to seal the gap between the edge of the soil core and the PVC pipe to prevent edgeflow. An outlet hole in the end cap allowed collection of the leachate. The assembled lysimeters were then put

Table 1. Location of field sites from which the lysimeters were taken, the soil type and New Zealand Soil Classification soil order and the mean initial Olsen P concentration of soil samples taken at the time of lysimeter collection at 0-75 mm depth. Values given in parentheses show one standard error of the measurement.

\begin{tabular}{lll}
\hline Sampling location & $\begin{array}{l}\text { Soil type } \\
\text { (NZ soil classification) }\end{array}$ & $\begin{array}{l}\text { Mean initial Olsen P concentration } \\
(0-75 \mathrm{~mm} \text { depth) }(\mathrm{mg} \mathrm{P} / \mathrm{kg})\end{array}$ \\
\hline $\begin{array}{l}\text { Ruakura Research Centre, } \\
\text { east of Hamilton, Waikato }\end{array}$ & $\begin{array}{l}\text { Horotui silt loam } \\
\text { (Typic Orthic Allophanic Soil) }\end{array}$ & $33.78(+/-2.09)$ \\
Woodland Research Station, & $\begin{array}{l}\text { Wiakiwi silt loam } \\
\text { east of Invercargill, Southland }\end{array}$ & $\begin{array}{l}\text { (Typic Firm Brown Soil) } \\
\text { Rerewhakaaitu Farm, }\end{array}$ \\
$\begin{array}{l}\text { Taupo sandy loam } \\
\text { south of Rotarua, Bay of Plenty }\end{array}$ & (Immature Orthic Pumice Soil) & $36.80(+/-2.60)$ \\
\hline
\end{tabular}

Table 2. Nitrate- $\mathrm{N}$ and ammonium- $\mathrm{N}$ concentrations in leachate and loss per lysimeter. The least significant difference at the $P<0.05$ level of significance is given for the comparison of soil order by treatment mean concentrations.

\begin{tabular}{|c|c|c|c|c|c|}
\hline \multirow[b]{2}{*}{ Soil } & \multirow[b]{2}{*}{ Treatment } & \multicolumn{2}{|c|}{ Mean loss (mg/lys/yr) } & \multicolumn{2}{|c|}{ Mean concentration (mg/L/yr) } \\
\hline & & $\mathrm{NH}_{4}-\mathrm{N}$ & $\mathrm{NO}_{3}-\mathrm{N}$ & $\mathrm{NH}_{4}-\mathrm{N}$ & $\mathrm{NO}_{3}-\mathrm{N}$ \\
\hline \multirow[t]{6}{*}{ Allophanic } & $\mathrm{ON} \& \mathrm{OP}$ & 0.61 & 1.39 & 0.09 & 0.24 \\
\hline & ON \& $1 / 2$ maintenance $P$ & 0.57 & 1.49 & 0.08 & 0.26 \\
\hline & $150 \mathrm{~kg} \mathrm{~N} / \mathrm{ha} / \mathrm{yr} \& \mathrm{OP}$ & 0.59 & 1.75 & 0.09 & 0.34 \\
\hline & $150 \mathrm{~kg} \mathrm{~N} / \mathrm{ha} / \mathrm{yr} \& 1 / 2$ maintenance $P$ & 0.57 & 1.43 & 0.11 & 0.33 \\
\hline & $300 \mathrm{~kg} \mathrm{~N} / \mathrm{ha} / \mathrm{yr} \& 1 / 2$ maintenance P & 0.55 & 2.28 & 0.10 & 0.52 \\
\hline & $300 \mathrm{~kg} \mathrm{~N} / \mathrm{ha} / \mathrm{yr} \&$ OP & 0.54 & 2.21 & 0.12 & 0.61 \\
\hline \multirow[t]{6}{*}{ Brown } & $\mathrm{ON} \& \mathrm{OP}$ & 0.58 & 1.30 & 0.08 & 0.25 \\
\hline & ON \& $1 / 2$ maintenance $P$ & 0.54 & 1.20 & 0.08 & 0.27 \\
\hline & $150 \mathrm{~kg} \mathrm{~N} / \mathrm{ha} / \mathrm{yr} \& \mathrm{OP}$ & 0.54 & 1.81 & 0.09 & 0.34 \\
\hline & $150 \mathrm{~kg} \mathrm{~N} / \mathrm{ha} / \mathrm{yr} \& \mathrm{1} / 2$ maintenance $P$ & 0.57 & 1.44 & 0.10 & 0.35 \\
\hline & $300 \mathrm{~kg} \mathrm{~N} / \mathrm{ha} / \mathrm{yr} \&$ OP & 0.55 & 1.88 & 0.12 & 0.42 \\
\hline & $300 \mathrm{~kg} \mathrm{~N} / \mathrm{ha} / \mathrm{yr} \& 1 / 2$ maintenance P & 0.54 & 1.57 & 0.18 & 0.4 \\
\hline \multirow[t]{6}{*}{ Pumice } & $\mathrm{ON} \& \mathrm{OP}$ & 0.65 & 1.30 & 0.08 & 0.20 \\
\hline & ON \& $1 / 2$ maintenance $P$ & 0.61 & 1.36 & 0.13 & 0.27 \\
\hline & $150 \mathrm{~kg} \mathrm{~N} / \mathrm{ha} / \mathrm{yr} \& \mathrm{OP}$ & 0.54 & 0.84 & 0.12 & 0.24 \\
\hline & $150 \mathrm{~kg} \mathrm{~N} / \mathrm{ha} / \mathrm{yr} \& 1 / 2$ maintenance $\mathrm{P}$ & 0.55 & 0.91 & 0.17 & 0.26 \\
\hline & $300 \mathrm{~kg} \mathrm{~N} / \mathrm{ha} / \mathrm{yr} \&$ OP & 0.57 & 1.36 & 0.13 & 0.32 \\
\hline & $300 \mathrm{~kg} \mathrm{~N} / \mathrm{ha} / \mathrm{yr} \& 1 / 2$ maintenance P & 0.54 & 0.79 & 0.13 & 0.22 \\
\hline LSD $_{05 \text { soil } x \text { trt }}$ & & 0.05 & 0.87 & 0.07 & 0.25 \\
\hline
\end{tabular}




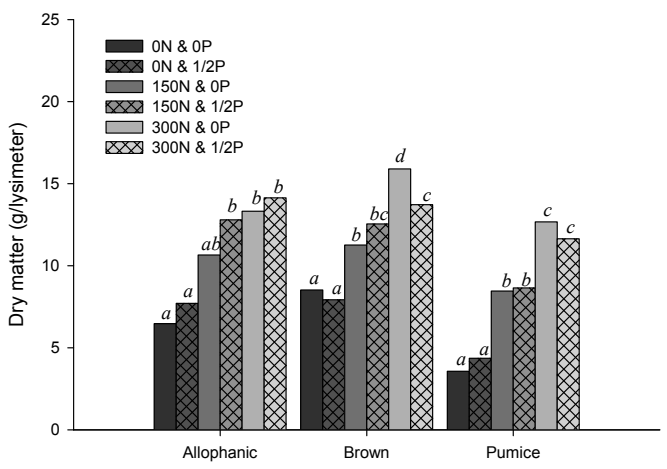

Figure 1. Mean total pasture DM yield from each lysimeter. The letters denote differences between treatments within each soil order at the $\mathrm{P}<0.05$ level of significance determined via Duncan's Multiple Range Test.

Abbreviations; $O N \& O P=$ zero $N$ and zero $P$ fertiliser applied, $O N \& 1 / 2 P=$ zero $N$ and half maintenance $P$ application, $150 \mathrm{~N} \& O P=150 \mathrm{~kg} \mathrm{~N} / \mathrm{ha} / \mathrm{yr}$ and zero $P$ application, $150 \mathrm{~N}$ \& $1 / 2 \mathrm{P}=150 \mathrm{~kg} \mathrm{~N} / \mathrm{ha} / \mathrm{yr}$ and half maintenance $\mathrm{P}$ application, $300 \mathrm{~N} \& \mathrm{OP}=300 \mathrm{~kg} \mathrm{~N} / \mathrm{ha} / \mathrm{yr}$ and zero $\mathrm{P}$ application and $300 \mathrm{~N} \& 1 / 2 \mathrm{P}=300 \mathrm{~kg} \mathrm{~N} / \mathrm{ha} / \mathrm{yr}$ and half maintenance $P$ application.

in place in a dedicated outdoor facility, comprising an elevated bank of soil into which the lysimeters were set allowing drainage into collection bottles below.

\section{Study conditions and leachate collection.}

The 1-year trial commenced in February 2011, and during this time there was a total of $600 \mathrm{~mm}$ of rainfall. To supplement rainfall over the drier summer months irrigation was applied to the lysimeters fortnightly, at a depth of $12.5 \mathrm{~mm}$ during February and March 2011 and from December to February 2012. Nitrogen was applied as urea at three rates, 0,150 and $300 \mathrm{~kg}$ $\mathrm{N} / \mathrm{ha} / \mathrm{yr}$, in split applications of 30 and $60 \mathrm{~kg} / \mathrm{ha} /$ yr across the grass growing season. Phosphorus was applied as superphosphate at two rates, zero and half maintenance $P$, in one application at the start of the trial. The half maintenance application corresponded to an application rate of 17,14 and $19 \mathrm{~kg} \mathrm{P} / \mathrm{ha} / \mathrm{yr}$ for the Allophanic, Brown and Pumice soils respectively. In addition, a maintenance application of sulphur (S) and potassium (K), taking into account the $\mathrm{S}$ supplied by superphosphate, was applied to each of the lysimeters at the start of the trial, as potassium sulphate and potassium chloride at an application rate of 38,32 and $42 \mathrm{~kg} \mathrm{~K} / \mathrm{ha} / \mathrm{yr}$ and 3, 11 and $10 \mathrm{~kg} \mathrm{~S} / \mathrm{ha} / \mathrm{yr}$ for the Allophanic, Brown and Pumice soils respectively. Pasture was cut every 30 days during the grass growing season. The clippings were removed and pasture DM determined.

Leachate samples were collected under vacuum the day following each rainfall event. If the volume collected was less than $1 \mathrm{~L}$ the leachate was frozen
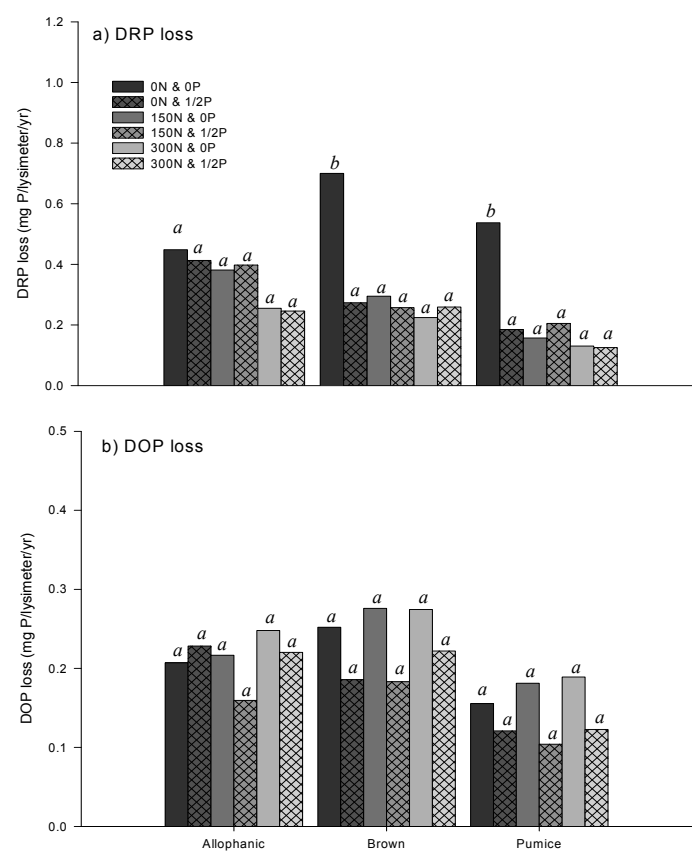

Figure 2. Mean total a) DRP loss b) DOP loss in leachate from the lysimeters. The letters denote differences between treatments within each soil order at the $\mathrm{P}<0.05$ level of significance determined by Duncan's Multiple Range Test.

Abbreviations; $\mathrm{DRP}=$ Dissolved reactive $\mathrm{P}, \mathrm{DOP}=$ Dissolved organic $P, O N \& O P=$ zero $N$ and zero $P$ fertiliser applied, $O N$ $\& 1 / 2 \mathrm{P}=$ zero $\mathrm{N}$ and half maintenance $\mathrm{P}$ application, $150 \mathrm{~N}$ \& $\mathrm{OP}=150 \mathrm{~kg} \mathrm{~N} / \mathrm{ha} / \mathrm{yr}$ and zero $\mathrm{P}$ application, $150 \mathrm{~N} \& 1 / 2 \mathrm{P}$ $=150 \mathrm{~kg} \mathrm{~N} / \mathrm{ha} / \mathrm{yr}$ and half maintenance $P$ application, $300 \mathrm{~N}$ $\& O P=300 \mathrm{~kg} \mathrm{~N} / \mathrm{ha} / \mathrm{yr}$ and zero $P$ application and $300 \mathrm{~N}$ \& $1 / 2 \mathrm{P}=300 \mathrm{~kg} \mathrm{~N} / \mathrm{ha} / \mathrm{yr}$ and half maintenance $\mathrm{P}$ application.

and bulked together with subsequent events, to reach $1 \mathrm{~L}$ cumulative total, to minimise analytical demand. Leachate samples were immediately filtered through a $0.45 \mu \mathrm{m}$ membrane and stored below $4^{\circ} \mathrm{C}$ before analysis the following day.

\section{Leachate analysis}

Filtered leachate samples were analysed for dissolved reactive $\mathrm{P}$ (DRP) and total dissolved $\mathrm{P}$ (TDP), after acid persulphate digestions (Rowland \& Haygarth 1997), using the molybdate blue method of Watanabe \& Olsen (1965). Dissolved organic phosphorus was calculated as the difference between TDP and DRP. For the first 2 months of the trial, nitrate and ammonium concentrations were determined using YSI Professional Plus multi-parameter meter with ion selective electrodes, calibrated with flow injection analysis (FIA) of selected samples. Thereafter, concentrations were determined via FIA.

\section{Statistical analyses}

A design with three soil orders and six different fertiliser 
treatments, three rates of $\mathrm{N}$ or $\mathrm{P}$ fertiliser and four replicates was used as a statistical model. The nutrient loss in the collected leachate and total DM yield were subjected to a two-way analysis of variance. Specific comparisons were made with the least significant difference at $\mathrm{P}<0.05\left(\mathrm{LSD}_{05}\right)$. All statistical analyses were carried out using the statistical package GenStat (GenStat Committee 2010).

\section{Results and Discussion}

Over the course of the trial there were 14 samplings, evenly spaced throughout the year.

Application of $\mathrm{N}$ fertiliser led to a significant increase in pasture $\mathrm{DM}$ production $(\mathrm{P}<0.01)$ across all soil types, while application of half maintenance $P$ fertiliser did not lead to a significant increase in production. This indicates that nitrogen was the limiting nutrient (Fig. 1). The increase in production was accompanied by a significant decrease in the amount of leachate collected $(\mathrm{P}<0.001)$ across all three soil orders and, for the Brown $(\mathrm{P}=0.033)$ and Pumice soil orders, a decrease in DRP loss as mg $\mathrm{P} /$ lysimeter/year $(\mathrm{P}<0.001)$ (Figure 2) with no significant difference between the two application rates (150 and $300 \mathrm{~kg} \mathrm{~N} / \mathrm{ha} / \mathrm{yr})$. The Allophanic soil order appeared to show a decrease in DRP loss, but this was not significant $(\mathrm{P}>0.05)$. Interestingly, for the Brown and Pumice soil orders, application of half maintenance $\mathrm{P}$ to the lysimeters receiving zero $\mathrm{N}$ application, significantly decreased DRP loss compared to the zero $\mathrm{N}$ - zero P treatment (Figure 2a). Furthermore, this decrease was of a similar magnitude to that following the application of $\mathrm{N}$.

The reasons for the decrease in $\mathrm{P}$ loss following a low rate of $\mathrm{P}$ application are unclear. While there was no significant difference in pasture DM between the zero $\mathrm{P}$ and half maintenance $\mathrm{P}$ applications (Fig. 1), the application of $\mathrm{P}$ may have increased primary production and biotic $\mathrm{P}$ demand leading to $\mathrm{P}$ being sequestered into the microbial $\mathrm{P}$ pool. Alternatively, the application of $\mathrm{P}$ fertiliser may have influenced the distribution of $\mathrm{P}$ within the different soil $\mathrm{P}$ pools, potentially decreasing the $\mathrm{P}$ availability for loss. Further work is required to investigate this.

There was no significant difference in DOP loss across the different treatments. Furthermore, DOP concentration in leachate collected from all of the lysimeters represented a large portion of the TDP and, with the exception of the zero $\mathrm{N}$ and zero $\mathrm{P}$ treatments, the DOP loss was of a similar magnitude to the DRP loss (Figure 2b). There is growing recognition that a significant portion of DOP can be bioavailable to algae through enzymatic hydrolysis (Whitton et al. 1991), but that the proportion of bioavailable DOP in leachate can be highly variable (McDowell \& Koopmans 2006;
Toor et al. 2003). Further work to characterise the DOP fraction in the leachate from the lysimeters is required to fully assess the effectiveness of the proposed strategy of increasing $\mathrm{N}$ additions to decrease $\mathrm{P}$ loss.

There was no significant difference in the annual nitrate or ammonium loss as $\mathrm{mg} \mathrm{N} / \mathrm{lysimeter} / \mathrm{yr}$ across all of the soil orders, and no spike in $\mathrm{N}$ loss was observed following the application of 150 or 300 $\mathrm{kg} \mathrm{N} / \mathrm{ha} / \mathrm{yr}$ compared to the zero $\mathrm{N}$ treatments (Table 2). There was a significant increase in mean nitrate concentration collected in leachate from the Allophanic lysimeters receiving $300 \mathrm{~kg} \mathrm{~N} / \mathrm{ha} / \mathrm{yr}$ compared to those receiving 0 or $150 \mathrm{~kg} \mathrm{~N} / \mathrm{ha} / \mathrm{yr}$, however due to a decrease in the amount of leachate draining from the $300 \mathrm{~kg} \mathrm{~N} / \mathrm{ha} / \mathrm{yr}$ treatment, presumably due to increased evapotranspiration as a result of increased pasture growth, this did not translate to an increase in nitrate loss. These results suggest that, based on a cut and carry system, the application of $\mathrm{N}$ fertiliser does not increase $\mathrm{N}$ loss. Hence, further work is required to determine if the large $\mathrm{N}$ inputs from urine patches have a similar effect on $\mathrm{P}$ loss as lower rates of $\mathrm{N}$ via urea.

\section{Conclusions}

The application of increased rates of $\mathrm{N}$ fertiliser to the Brown and Pumice soil orders decreased P loss in leachate, largely as DRP, and increased pasture DM compared to soils receiving zero $\mathrm{N}$. There was no effect on nitrate or ammonium loss. No significant treatment effect was observed for the Allophanic soil order, and the application of increased nitrogen led to an increase in nitrate concentration in the leachate, but not an increase in nitrate loss as $\mathrm{mg} \mathrm{N} / \mathrm{lysimeter/yr.} \mathrm{This} \mathrm{study}$ demonstrates the potential of increasing $\mathrm{N}$ fertilisers as a strategy to decrease $\mathrm{P}$ loss from high $\mathrm{P}$ soils within a short timeframe while maintaining yields when based on a cut and carry system for Brown and Pumice soil orders but suggests that the strategy may not be suitable for Allophanic soil orders. Following the reduction in soil $\mathrm{P}$ concentrations, grazing can resume on this pasture in accordance with best management practices.

\section{REFERENCES}

Dodd, R.J.; McDowell, R.W.; Condron, L.M. 2012. Predicting the changes in environmentally and agronomically significant phosphorus forms following cessation of phosphorus fertiliser applications to grassland. Soil Use and Management 28: 135-147,

GenStat 13. 2010. GenStat for Windows. 13th edn. VSN International Ltd, Oxford, UK.

Gilbert, N. 2009. The disappearing nutrient. Nature 461: 716-718. 
Gillingham, A.G.; Richardson, S.; Power, I.L.; Riley, J. 1990. Long term effects of withholding phosphate application on North Island hill country: Whatawhata Research Centre. Proceedings of the New Zealand Grassland Association 51: 11-16.

Hewitt, A.E. 2010. New Zealand Soil Classification. Landcare Research Science Series No. 1. 3rd Edition.

Koopmans, G.F.; Chardon, W.J.; Ehlert, P.A.I; Dolfing, J.; Suurs, R.A.A.; Oenema, O.; van Riemsdijk, W.H. 2004. Phosphorus availability for plant uptake in a phosphorus-enriched noncalcareous sandy soil. Journal of Environmental Quality 33: 965-975.

McCollum, R.E. 1991. Buildup and decline in soil phosphorus: 30-year trends on Typic Umprabuult. Agronomy Journal 83: 77-85.

McDowell, R.W.; Koopmans, G.F. 2006. Assessing the bioavailability of dissolved organic phosphorus in pasture and cultivated soils treated with different rates of nitrogen fertiliser. Soil Biology and Biochemistry 38: 61-70.

McDowell, R.W.; Monaghan, R.M. 2002. The potential for phosphorus loss in relation to nitrogen fertiliser application and cultivation. New Zealand Journal of Agricultural Research 45: 245-253.

Morton, J.D.; Roberts, A.H. 1999. Fertiliser use on New Zealand sheep and beef farms. New Zealand Fertiliser Manufacturers' Research Association,
Newmarket, New Zealand.

Perring, M.; Edwards, G.; de Mazancourt, C. 2009. Removing phosphorus from ecosystems through nitrogen fertilization and cutting with removal of biomass. Ecosystems 12: 1130-1144.

Roland, A.P.; Haygarth, P.M. 1997. Determination of total dissolved phosphorus in soil solutions. Journal of Environmental Quality 26: 410-415.

Sharpley, A.N.; Chapra, S.C.; Wedepohl, R.; Sims, J.T.; Daniel, T.C.; Reddy, K.R. 1994. Managing agricultural phosphorus for protection of surface waters: issues and opinions. Journal of Environmental Quality 23: 437-451.

Toor, G.S.; Condron, L.M.; Di, H.J.; Cameron, K.C.; Cade-Menun, B. J. 2003. Characterization of organic phosphorus in leachate from grassland soils. Soil Biology and Biochemistry 35: 1317-1323.

Watanabe, F.S.; Olsen, S.R. 1965. Test of an ascorbic acid method for determining phosphorus in water and $\mathrm{NaHCO}_{3}$ extracts from soil. Soil Science Society of America Proceedings 29: 677-678.

Whitton, B.A.; Graingerm S.L.J.; Hawley, G.R.W.; Simon, J.W. 1991. Cell-bound and extracellular phosphatase activities of cyanobacteria isolates. Microbial Ecology 21: 85-98. 
